\title{
ReSEARChArticle
}

\section{Blue- green algal biofertilizer and growth response of rice plants}

\author{
ASHMRITA MAHATO AND RADHA SAHU
}

\begin{abstract}
SUMMARY
Blue- green algae BGA also called Cyanobacteria are the only source of nitrogenous biofertilizers produced naturally with no energy cost of mankind. Biofertilizer are the micro-organism which are for soil enrichment. The main sources of biofertilizer are bacteria, Cynobacteria and Mycorrhizal fungi. Bacteria and Cynobacteria function as a biofertilizer due to the property of nitrogen fixation. (Conversion of molecular nitrogen into nitrogen compound). They are photoautotrophic microbes which utilize solar energy to reduced atmospheric dinitrogen to ammonia. They have a very simple inorganic requirement for growth and their mass production is much cheaper and easier than that of conventional chemical fertilizer. In India there are about 40 centers for production and multiplication of these blue - green algal Biofertilizer. The flakes of blue-green algae are now recommended at the rate of $10 \mathrm{~kg} /$ ha ten day after transplantation of rice and their powdered packets are being sold in the Agriculture University. Agriculture Research Institute, New Delhi has reported that $20-30 \mathrm{~kg} / \mathrm{ha}$ nitrogen was fixed by them. Field experiment was conducted at Ranchi with rice IR36. The soil was acidic having PH 6.0.Two rice field $20 \mathrm{~m}^{2}$ was prepared one with BGA and other without BGA acted as control rice seedlings were transplanted in the flooded field. Ten days after transplantation of rice plants BGA biofertilizer were inoculated in ratio of $0.04: 0.05 \mathrm{~kg} / \mathrm{m}^{2}$. It was observed that the inoculates contained mixture of Gloeocapsa Plectonema, Oscillatoria, Anabaena, Nostoc, Cylindrospermum, Scytonema, Calothrix, Anabaeanopses, Aulosira, Fischerella etc. During the experiment it was observed that the field with algal inoculates showed the rice plant has bright -green thick fleshy having large number of leaves. The tillers were seen 80 days after the rice plants and number of food grains were thick elongated and healthy as compared with control plants. The grain yield was found to be increased to be in the tune of 10-30 per cent over the control. This observation clearly indicates that the application of BGA manure can replace the chemical fertilizers.
\end{abstract}

Key Words : Biofertilizer, BGA, Cynobacteria, Rice plant

How to cite this article : Mahato, Ashmrita and Sahu, Radha (2017). Blue- green algal biofertilizer and growth response of rice plants. Internat. J. Plant Sci., 12 (1): 68-71, DOI: 10.15740/HAS/IJPS/12.1/68-71.

Article chronicle : Received : 05.08.2016; Revised : 25.11.2016; Accepted : 21.12.2016

\section{MEMBERS OF THE RESEARCH FORUM}

Author to be contacted :

RADHA SAHU, Department of Botanty, Algal Biotechnology

Laboratory, Ranchi University, RANCHI (JHARKHAND) INDIA

Address of the Co-authors:

ASHMRITA MAHATO, Department of Botanty, Algal Biotechnology

Laboratory, Ranchi University, RANCHI (JHARKHAND) INDIA 